\title{
Historicising The Women's Manifesto for Ghana: A culmination of women's activism in Ghana
}

\author{
Cyrelene Amoah-Boampong \\ Senior Lecturer \\ Department of History \\ University of Ghana, Legon, Ghana \\ E-mail: camoah-boampong@ug.edu.gh
}

Submitted: April 13, 2018/ Accepted: October 20, 2018 / Published: December 3, 2018

\begin{abstract}
Women are one of Ghana's hidden growth resources. Yet, Ghanaian women have been marginalized from the developmental discourse by a succession of hegemonic political administrations. At best, Ghanaian women were said to have a quiet activism, although each epoch had its own character of struggle. Bringing together history, gender and development, this article examines the historical trajectory of female agency in postcolonial Ghana. It argues that through the historisation of women's activism, Ghanaian women's agency and advocacy towards women's rights and gender equality concerns rose from the era of quiet activism characterised by women's groups whose operations hardly questioned women's social status to contestation with the state epitomized by the creation of The Women's Manifesto for Ghana in 2004 which played a critical role in women's collective organisation and served as a key pathway of empowerment.
\end{abstract}

Keywords: women, activism, empowerment, Women's Manifesto, Ghana

\section{Introduction}

Globally, there exists gender disparities in human development. According to the 2030 Agenda for Sustainable Development, gender equality is fundamental to delivering on the promises of sustainability, peace and human progress (United Nations Development Programme (UNDP), 2016). Ghana adopted all 17 goals set to end poverty and ensure prosperity for all. Yet, in 2018, Ghana ranked 140 in the world in the UNDP's Gender Inequality Index, with a score of 0.592 (UNDP, 2018). Ghanaian 
women's equality has been met halfway by socio-historical disparities in decision-making power and access to resources (Tsikata, 1989, 2009; Manuh, 1991, 1993; Mama, 2000, 2005; Cornwall \& Anyidoho, 2010; Adomako \& Asiedu, 2012; Cornwall, 2016; Darkwah, 2016). The process of governance has been malecentred creating the erroneous impression that the process of governance is the preserve and entitlement of men. In the opinion of Nzomo (1994), the battle for changing the relations of power between men and women, and the right to decision-making processes in Africa has been an uphill battle against patriarchy, poverty, and autocracy (p.17).

While attention has been focused on the state's hegemony and political marginalization of women (Anunobi, 2002; Coffee \& Bolzendahl, 2011; Hamah, 2015; Okrah, 2018), it obscures the narrative of women's success in connecting their issues with other minorities through coalition building and collective action. Within the first two decades of the twenty-first century, Ghanaian women recognized their power within and acted together with other women to exercise power with and increase their solidarity and ability to contest and change power structures through The Women's Manifesto for Ghana. This non-partisan, political document was a collaborative effort of women who cut across political, regional, educational and ethnic boundaries in the country. It explicitly outlined the common demands of Ghanaian women as a prerequisite for ameliorating the power disequilibrium and achieving gender equality and equity and sustainable national development. Ghana's Women's Manifesto also provided a platform for influencing government to address women's rights issues in the 2004 elections and beyond. Women were empowered to use their votes as a bargaining tool and to "ensure political party accountability as they would ultimately be assessed on the basis of where they stand in relation to issues that concern women as outlined in the Women's Manifesto" (The Women's Manifesto for Ghana, 2004, p. i). 


\section{Analytical framework}

This study adopts a historical perspective to examine women's collective mobilization in Ghana. Ghana is an ideal case study as it ratified all major international and regional women's rights documents such as the Convention on the Elimination of all forms of Discrimination Against Women (CEDAW) 1989; United Nations World Conference on Human Rights in Vienna, 1993; Beijing Platform for Action 1995; Millennium Declaration of 2000; African Union Solemn Declaration on Gender and Advancement of Women, 2004; 2030 Agenda for Sustainable Development, 2015; and the Revised ECOWAS Treaty and Gender Policy 20152020. In addition, Ghana formulated its National Gender Policy in 2015. This policy enhances women's rights and provides a clear framework for addressing gender inequalities deeply rooted in Ghanaian society.

The study adopts part of Mama (2000) and Manuh and Anyidoho (2008)'s framework for analysis of national machinery and extends it to women's rights coalitions, by examining the historical context and processes out of which the Women's Manifesto Coalition (WMC) evolved. Here, the study explores the historical trajectory from pre-colonial women's activism to the creation of WMC. It interrogates the discourse on women's empowerment in development that focuses on individualism and economic empowerment and ultimately undermines women's "ability to reflect critically on the nature of unjust social and economic relations and institutions and act to change them" (Cornwall, 2014, p. 5). It contends that the marginal representation of women at the national level is indicative of the disempowering reality that Ghanaian women experience. The Women's Manifesto for Ghana, thus, provides a platform for the progression of Ghanaian women from a state of disempowerment to empowerment in order to achieve gender equality and equity.

In this regard, the study offers an interpretive analysis of the history of women's power in Ghana based on Amina Mama's interviews with Ghana's leading feminist activists, open-ended conversations with Dr. Rose Kutin, semi-structured interviews 
with staff at the Ministry of Gender, Children and Social Protection and ABANTU for Development as well as content analysis of The Women's Manifesto for Ghana. It analyses the development of Ghanaian women's authority and extends the theory of women's empowerment by pointing to the relevance of networks and coalitions such as the Women's Manifesto Coalition in reshaping the power dynamics between women and the state in post-colonial Ghana. By so doing, the WMC contested the power structures and relations that deny women autonomy in their lived experiences.

\section{Theoretical framework}

The experiences of Ghanaian women's organisations within the framework of empowerment underpins this study. The concept of empowerment has been contested and conceptualised differently by scholars and advocates. In the 1980s and 1990s, women's empowerment defined by feminist scholars was focused on transforming power relations to the advantage of women's rights and an increase in gender equality and equity (Batliwala, 1993, 2007; Kabeer, 1994, Rowlands, 1997; Sen, 1997). This meant empowerment is not something that can be done for or to women. It requires women being conscious of the power inequalities in society and acting to bring about structural changes that would transform unjust and unequal power relations. With this interpretation of empowerment came a focus on enabling women express their collective interests to organise (power with); to develop the necessary skills and access resources to attain their ambition (power to) and to articulate their own aspirations and strategies for change (power within). Thus, empowerment became the process of contesting and transforming existing power relations and acquiring more control over the sources of power.

Currently, Cornwall (2016) notes that empowerment has become a slogan exploited by multinational entities, nongovernmental organisations and development agencies. In the process, the grassroots struggles to confront and transform the deep, unjust and unequal power relations from the 1990s has been lost (Narayan, 2002; Alsop, Heinsohn \& Somma, 2005). In its place is 
an overemphasis on economic dimensions of empowerment which stress access to credit, paid work and ownership of productive resources for individual women to improve their personal situations (Malhotra et al., 2002; Eyben \& Napier-Moore, 2009; World Bank, 2011; Bradshaw, 2013). In this latter conceptualisation, it is assumed that the improvement in economic conditions will necessarily transform all aspects of women's lives. This assumption does not take cognisance of empowerment as a multidimensional concept as expressed in the works of feminist scholars (Tsikata \& Darkwah, 2014; Cornwall, 2014, 2016) in which what empowers one woman does not necessarily apply to another and a woman's empowering experience in one arena does not automatically translate into agency in all spheres of her life.

This study defines women's empowerment as the creation of an enabling environment through policies and the elimination of cultural constraints that make it difficult for women to achieve their highest potential. Empowerment here implies an active and interactive process between Ghanaian women and their environment. It results in a change from a passive, powerless state epitomised by the marginalisation of women's associations throughout the 1980s and 1990s, to an active state commencing in 2000 and climaxing with the creation of a Women's Manifesto Coalition in 2004. Through the Women's Manifesto Coalition (WMC), Ghanaian women broke the chains of false consciousness initiated by patriarchal society and reinforced by the colonial structure and discarded the notion of worthlessness into the belief and acceptance of themselves as assertive citizens.

Power in this study implies the processes that led Ghanaian women to perceive themselves as able and entitled to make decisions. This interpretation is beyond the mere integration of Ghanaian women into the existing socio-economic and political structures through increased decision-making authority. This definition of power, in turn sees empowerment as a process by which oppressed women in Ghana gained critical consciousness and acted to control their lives by taking part in the Women's Manifesto Coalition 
to shape the context and structure of their daily existence and to participate in a movement of social transformation in Ghana. In this regard, Ghanaian women recaptured salient aspects of their pre-colonial gender complementarity and solidified their agency and activism in a bid to lead to social transformation and structural change.

\section{Women's foundational activism}

Women's activism in Ghana has a long history as women have long engaged in social, political and economic concerns within their communities. During the pre-colonial era, among the diverse ethnic groups in Ghana, gender relations was modelled on a dual-gendered system of political authority. Men and women occupied leadership positions that were analogous and balanced each other (Arhin, 1983; Aidoo, 1985; Amadiume, 1987; Brydon, 1996; Odotei, 2006; Fallon 2008). The institution of the queen mother, ohemaa (Akan), manye (Ga-Dangbe) and mamao (Ewe) was a crucial avenue of women's empowerment. For instance, the Asantehemaa (queen mother of Asante) played a crucial role in governance as she nominated the candidate to be considered Asantehene (king of Asante) in consultation with lineage heads. Beyond her function as kingmaker, she deliberated on issues of distribution of land, the declaration of war and controlled women's affairs (Arhin, 1983; Aidoo, 1985; Odotei, 2006). In northern Ghana some leadership roles were reserved for women. For instance in Mamprugu, female chiefs occupy the skins of Dindani and Samini. The Dindani-Tamboku chieftaincy position is the preserve of the daughter of the Nayiri (paramount chief of the Mamprugu traditional area) (Odotei, 2006). The Dindani Pona notifies eligible sub-chiefs about the vacancy of the skin; she occupies the palace and takes charge of widows on the death of the chief; she settles disputes in the community with her council of elders and she also preforms ritual functions during sacrificial offerings (Odotei, 2006, p. 84).

The dual-gendered system of traditional leadership prevented any wielder of traditional political authority from 
monopolizing power. It also underpinned leadership positions for women, notwithstanding the patriarchal nature of Ghanaian society. Many of the women who held leadership positions were of regal status. However, these royal women did not exercise their political power solely through their relationship with men. The existence of parallel leadership positions in pre-colonial Ghana clearly points to the fact that egalitarian gender relation was conceivable, and women had transformative power (Manuh, 1991; Akyeampong \& Obeng, 1995; Fallon, 2008). Indeed, women participated in wars as leaders of the army. The case of Queen Adisa of Nanumba, Nana Dokua of Akyem and Yaa Asantewaa of Asante are all well known in Ghanaian history.

From a situation of holistic gender relations in traditional African societies during the pre-colonial era, women were disempowered, and their agency diminished during the colonial period. The introduction of Victorian values of domesticity with the distinction between the male public sphere and female private sphere altered women's power relations and reinforced western notions of gender inequality, which systemised and subordinated Ghanaian women at the expense of their traditional gender complementarity (Allman, Geiger, \& Nakanyike, 2002; Berger, 2003; Sheldon, 2017). Yet, elite women collectively mobilized resources through the formation of charitable associations based on welfare concerns to create limited space that they could hold their own. These charitable associations included the Ladies Mutual Club in Sekondi, Young Ladies' Christian Association and the Native Ladies of Cape Coast. These organizations tried to empower Ghanaian women. For example, the Native Ladies of Cape Coast relied on the "Ladies Column" in the Western Echo newspaper to articulate women's interest. Yet, majority of these associations were geared at moulding women in the image of the Victorian ideal woman as mothers and wives (Allman \& Tashjian, 2000; Akurang-Parry, 2004). These welfare associations also suffered from legitimacy issues as they received some of their support from the British colonial government. Overall, the colonial period was 
a setback for Ghanaian women's agency as the women's welfare groups barely challenged women's social status.

\section{Post-colonial breakthrough}

Unfortunately, the historical pattern established by the British colonizers held sway into the immediate post-colonial era. Successive Ghanaian administrations failed to genuinely prioritise women's civil and social rights. Indeed, even though women partook in rallies, protests and boycotts that facilitated the process of decolonization, especially market women and their economic power, any dream of equality was short lived. Women's activism during this era was still propelled by socio-economic issues and did not address specific women's rights concerns (Tsikata, 2009).

A major advancement in the course for women came with the promulgation of the Representation of the People (Women Members) Act in 1959. This act allowed the National Assembly to appoint ten women, as additional members, to parliament, representing ten percent of the Assembly (Fallon, 2008, p. 30). Patriarchal mentality was swiftly evident when the Opposition Member of Parliament, Mr. Victor Owusu, referred to the female parliamentarians as "a sprinkling of 'lip-sticked' and 'pan-caked' faces of doubtful utility to the deliberations of the House" (Parliamentary Debates, 1960, p. 24). Women's activism received another blow when President Kwame Nkrumah declared Ghana a one-party state in 1964 and regulated the activities of governmental and non-governmental women's organisations (Tripp \& Casimiro, 2009, p. 45). Through the creation of a single women's organisation (National Council of Ghana Women-NCGW), the Convention People's Party (CPP) disempowered women and kept them depoliticised as the NCGW focused on welfare concerns and educational policy campaigns instead of advocating for women's rights until its overthrow in 1966.

The period from 1966 to 1981 was characterised by an onslaught of successive military regimes that eroded the marginal gains women won during the CPP era. The military regimes were not gender-sensitive and had few women in their ranks. 
They were unenthusiastic about women's political participation and influence in public life. Few women were offered or took up public office under these dictatorial regimes (Allah-Mensah, 2005). Interestingly, it was during this period of military rule that the National Council for Women and Development (NCWD) was established in 1975 in the wake of feminist consciousness and the Women's Liberation Movement in the West. Focusing on incomegenerating activities to improve women's economic well-being rather than social transformation issues, the NCWD suffered from a lack of sufficient political will to be able to initiate policy decisions that would generate support for the promotion of gender equality and extend women's empowerment. Furthermore, the deterioration in the Ghanaian political climate did not bode well for the sustained development of women's activism. It was no wonder that this period also marked a hiatus in women's mobilisation at the national level for over a decade. Instead, there was an explosion of local women's welfare and professional groups quietly addressing women's issues.

During this politically unstable period, brief civilian governments came to power. The first was the Progress Party (1969 to 1972), led by Dr. K. A. Busia. Unfortunately, the Progress Party stifled the activities of mass movements especially the Trade Union Congress, which was dissolved in 1971. This repressive atmosphere was a stumbling block to efforts to build a strong civil society base for women (Tsikata, 2009). The People's National Party (PNP) administration under Dr. Hilla Limann also failed to prioritise women's participation in governance. Women constituted 2 out of 140 members of parliament under the Progress Party and their number rose to 5 under the PNP government (Prah, 2007, p. 7).

The Provisional National Defence Council (PNDC) government appeared to change the tide in favour of women. A few women were appointed to political office. These included Susan Alhassan, as member of the Council of State, Dr. Mary Grant, as Secretary for Health and later member of the Council of State, Joyce Aryee, Secretary for Information, Ama Ata Aidoo and Lucy 
Enin-Annan, as members of the PNDC (Adjei, 1994, pp. 198-200). However, this wind of change did not impact the mass of Ghanaian women in the informal sector, especially market women.

The PNDC regime was challenged by an economic crisis in the late 1970 s and early 1980 s characterised by a rise in the price of food and other necessities accompanied by shortages in fuel and high unemployment rate. This sorry state of the economy led to a black market which affected the cost of living and resulted in compulsory price controls (Nugent, 1996, 2015; Oquaye, 2004; Gocking 2005). The Daily Graphic caption on Monday March 1, 1982 read, "Control Prices Out." This article drew attention to the new price list in which real wax print was to sell at 400 cedis, one bar of soap at 7 cedis 20 pesewas; a carton of fish at 450 cedis; cooking oil at 112 cedis and a bag of maize at 480 cedis with an exchange rate of 2.720 cedis to one dollar (US Department of Treasury, 1982; Daily Graphic, 1982, p. 3).

In this atmosphere, market women who controlled the heart of commercial activity in the country were accused of being economic saboteurs and blamed for exacerbating the economic woes through high prices of commodities and hoarding essential goods. Targeted as enemies of the state, publicly humiliated in the media as symbols of corruption and moral disintegration, market women were beaten, their wares confiscated, and their shops closed by PNDC functionaries (Manuh, 1993, pp. 180-181). The targeting of market women further repressed women's activism, which fell back on informal networks of association, amidst a culture of silence. Women increasingly maintained their distance from political issues in Ghana.

Fortunately, the PNDC's initial hostility to women was shortlived. The United Nations, International Monetary Fund and the World Bank influenced a new gender posture. In a bid to alleviate the economic crisis and implement the Structural Adjustment Policies of the Bretton Wood institutions, most African nations, including Ghana, were required to demonstrate commitment to gender issues. Under the auspices of the Decade for Women (1975-1985) and the 
subsequent Women in Development approach, governments were called upon to mobilise women for their development agenda.

The PNDC administration appropriated this developmental framework and used gender politics for its own ends. In this regard, the 31st December Women's Movement was formed in 1982 and Nana Konadu Agyeman Rawlings, wife of the PNDC chairman, Flight Lieutenant Jerry John Rawlings, became president of the organisation. The ostensive purpose of the 31st December Women's Movement was to encourage women to become involved in the affairs of the Ghanaian state; however, it acted as an apparatus to mobilise women under the PNDC's patronage networks expanding its female constituencies. Despite the provision of seed money to start income-generating businesses, a positive implication for women's empowerment, Ghanaian women were subtly co-opted to join the organisation (Tsikata, 1989, pp. 73-93). Women attended party rallies and meetings and participated in domestic frivolities of singing, dancing and preparing meals for visiting dignitaries rather than advocating for women's rights.

Basically, the PNDC through the 31st December Women's Movement, reinforced women's disempowerment and political marginalisation and monopolised the space for gender work. The only exception to the picture of state co-option was the International Federation of Women Lawyers (FIDA) which mobilised women without state influence on women's legal rights (Tsikata, 2009, pp. 185-192). However, FIDA's mobilisation was in an individualistic and instrumentalist fashion. It did not address the core mission of transforming the structural basis of gender inequality that women's rights activists held dear. Indeed, the PNDC's co-option of key women's organisations allowed the government to pay lip service to the question of women's rights and gender equality. It effectively marginalised women's leadership and channelled women's collective action into narrow issues based on self-interest rather than contesting the state for space in the political arena. 


\section{Rebirth of women's activism}

During the period of state appropriation of women's agency, Ghana was undergoing a transition from military rule to a democratic dispensation. The resurgence of Ghanaian women's empowerment and activism in this transition was evident in the creation of a new constitution in 1992. Women participated in the Constituent Assembly. However, these women were drawn from supporters of the PNDC regime and followers of the $31^{\text {st }}$ December Women's Movement such as market women. Indeed, the focus on market women was a welcome change from the PNDC's previous antagonism. Yet, it was contentious. These market women were either the political faithful or held allegiance to the 31 st December Women's Movement and its leader. None of these women truly represented the mass of Ghanaian women and their issues.

Furthermore, the uncertainty surrounding the general elections in 1992 and the fragmentation of autonomous women's organisations complicated the situation for women. By 1996, women became bolder as they recognised the change in political structure and the opportunity that democratisation created to assert their voice and contest the state in the public sphere. At the same time, new associational autonomy arose as the era of quiet activism based on welfare associations and community organisations was cast off with the registration of a plethora of women's coalitions (Manuh, 2007; Tsikata, 2009). These women's coalitions such as Network for Women's Rights in Ghana (NETRIGHT) formed in 2000, ABANTU for Development, Gender Violence Survivors Support Network (GVSSN) hosted by the Women's Initiative for Self-Empowerment (WISE), Women's Manifesto Coalition (2004) and the Domestic Violence Coalition (initially hosted by the Ark Foundation, itself established in 2000) were formed around specific goals and were emboldened by the decline in invincibility of the 31st December Women's Movement. Bolstered by the 1992 constitution, women's coalition groups used women's collective identity to socialise women to participate in the public sphere. As Tsikata (2009) argues, the networks lent a collective spirit to the work of women's rights in Ghana and created a platform for 
women's group to engage in discussions about issues concerning them. Ghanaian women activists realized that working in their individual units had little impact on the state. Thus, in order to create real social transformation, they needed to work together as a collective and engage the state as a united front.

Using the democratic process to their advantage, and in the face of the patriarchal and chauvinistic nature of the state, women's organisations called on the newly elected democratic government of the National Democratic Congress (NDC) led by Jerry John Rawlings to include women and address women's concerns. They publicly questioned the state on women's rights issues, especially the growing reports of violence against women. In this regard, coalitions of women's groups mobilized and drafted a Domestic Violence Bill and put pressure on the government to pass it. An integral part of this bill was the repeal of Section $42(\mathrm{~g})$ of the Criminal Code, 1960 (Act 29) which states, "the consent given by a husband or wife at marriage for the purpose of marriage, cannot be revoked until the parties are divorced or separated by a judgment or decree of a competent Court" and include a new Section I (b) (ii) which forbids "sexual abuse, namely the forceful engagement of another person in any sexual contact whether married or not" (Fallon, 2008, p. 100). The crust of the issue was to draw attention to marital rape and outlaw sexual abuse within conjugal relations. However, Ghanaian patriarchal society saw the repeal of Section 42 (g) as an affront to male power and sensibilities. The state presented the inclusion of marital rape in the Domestic Violence Bill as problematic and a "western concept that would destroy marriages and lead to moral decay of the larger society" (Fallon, 2008, p. 106).

Ultimately, the Domestic Violence bill was passed in February 2007 and the marital rape section, couched in terms of cultural imperialism was deleted. Section 42 (g) was not repealed, rather Section I (b) (ii) was reframed to read, "the use of violence in the domestic setting is not justified on the basis of consent." Interestingly, in June 2007 as part of a statutory review, the Government of Ghana quietly repealed Section 42 (g). This was 
a clear victory for the women's coalition groups that continued to pressurise the state to live up to its responsibilities in terms of safeguarding the rights of women.

The epitome of violence against Ghanaian women came to a crescendo with a spate of serial killings. It started as isolated incidences in 1997 and built up to major public embarrassment for the NDC government in 2000, with the brutal murder of over twenty Ghanaian women. The Daily Graphic newspaper run the headline, "Another mystery murder rocks Accra: Victim No. 25 and still no clues" on Monday July 3, 2000. The article noted, "Accra has been rocked by another mysterious murder of women, less than a week after two other women were murdered under similar circumstances" (Daily Graphic, 2000, p.1).

With the tally of victims reaching 30 , it became quite apparent to Ghanaian women that the police were ill equipped to apprehend the culprits. A coalition of women's groups drew on their gendered networks and formed a pressure group, known as Sister's Keepers. They staged demonstrations and marched to the Osu Castle, the seat of government to protest. Dressed in mourning clothes with red bands around their heads, the women demanded the President and Parliament treat the gruesome murders of women as a national crisis. They also called on the government, as a matter of urgency, to deploy all resources available to embark on a comprehensive programme aimed at apprehending the culprits. The women's right activists expressed dismay at the fact that days after the gruesome murder of a woman at another suburb in Accra, the Interior Minister had issued no official statement. They, therefore, called on Parliament to immediately summon the Inspector-General of Police and the Head of the National Security Council to answer questions on the murders.

The message of women's right activists was clear. President Rawlings and his party, the National Democratic Congress, had effectively dismissed the murders and did not value women or their livelihood. The women's coalition encouraged Ghanaians to vote a different party into government, one that would take 
the serial killings seriously and bring the murders to an end. The opposition National Patriotic Party (NPP) heard the cries of women and its presidential candidate, John Agyekum Kufuor, specifically addressed the issue of the serial killings at diverse campaign stops and promised to end the murders. Kufuor (2001) stated:

I therefore condemn in the strongest possible terms the murders of women that have plagued us and have thus far not been solved. I shall do my best to ensure that the police give the highest priority to solving the murders and bringing the perpetrators to book. Nothing should stand in the way, and I promise that my administration will give all the help needed to enable the police get to the bottom of these gruesome murders. With God's help and guidance, we shall soon see the end of this most unpleasant chapter in our history. (p. 2)

On January 7, 2001 John Agyekum Kufuor, was sworn in as the second President of the Fourth Republic at a colourful ceremony at the forecourt of the Parliament House in Accra. The new administration quickly sprang into action and on May 16, 2001, a 36-year-old driver mechanic, Charles Quansah, confessed to the serial murders (Daily Graphic, 2001). Beyond solving the serial murders of women, President Kufuor's administration increased hope for open and unregulated women's activism when he expressed his gratitude to women in his inaugural address in 2001. Kufuor (2001) stressed:

I salute you, the women of Ghana; I salute your hard work and your dedication. You deserve to be treated with respect, and the burden you carry on all our behalf must be lightened. I salute you for the uncomplaining way you look after all of us. What reputation we have as Ghanaians comes from the love and attention given us by our mothers, sisters and wives. (p. 2)

Furthermore, the NPP administration established a Ministry of Women and Children's Affairs (MOWAC) to ensure that women 
took their rightful place by their men-folk and guarantee that all policy was pervaded with due consideration for the interest of women. Mrs. Gladys Asmah was appointed to head this ministry. President Kufuor (2005) further asserted:

Women and children have been traditionally handicapped over the years. There have been agencies and organisations, which have championed their causes over the years. The new Ministry of Women's and Children's Affairs (MOWAC) institutionalises these efforts in a systematised, sustained and more effective manner right at the centre of government. Government is pursuing with greater vigour, interventions for empowering them with technical and financial support to play a more active role in the nation's wealth creation programmes as well as in education and other social and political fields. (p. 5)

Undoubtedly, the Ministry of Women and Children's Affairs appeared to be a good opportunity to initiate concrete policy measures that would lay the foundation for greater responsiveness to gender concerns in Ghana. However, women's right activist had issues with this ministry. They argued that the ministry ghettoized women's issues and limited its priorities to livelihood questions and less on undertaking a social transformational agenda (MensahKutin, 2005). Additionally, the new Ministry was woefully underresourced by the state and female members of Parliament felt that the creation of the Ministry of Women and Children's Affairs was a symbolic gesture to the women's activist community to concede to women's pressure on the state. The new Ministry was seen as window dressing and a fashion statement to comply with current gender thinking and was not empowering (Mama, 2000).

These concerns of women's right activists were confirmed by the low representation of women at the legislative level as only 19 out of 200 members of Parliament were women. The NPP administration may have opened political space for women but much more needed to be done to rectify gender inequality and 
restore equity to women. Indeed, the problem in promoting gender equality has never been the lack of necessary frameworks, but the lack of political will. The NPP's eloquently formulated policies became empty slogans during their top-down implementation. The state lacked not only the political will but also the ability to tackle the central issues of women's marginalization. Thus, there was a clear need for social and political groups, such as the Women's Manifesto Coalition, generated by women themselves which could lead to change from below and support the transformatory goals of empowerment.

\section{Democracy and women's mobilisation}

The wave of democratisation that swept across Ghana in the 1990s created the expectation of a more gender equitable state. Ironically, the process of democratisation did little to improve women's political influence within the state. The state remained an inherently masculine structure and grew in strength at the expense of women. Women in Ghana, in spite of their major contributions and legacy of activism, barely occupied key decision-making positions. On the off chance that they did, "the nature and character of their roles and responsibilities tend to reinforce the notion that women are merely suitable to address survivalist questions rather than exercise power for socio-economic development" (MensahKutin, 2005, p. 5).

The lack of progress in redressing gender inequality was much more staggering as Ghana continued to sign all major international protocols that gave recognition to concerns of women and gender equality. In accepting the Beijing Platform for Action (PFA), Ghana agreed to the elimination of discrimination against women in the political platform and public life of the country (PFA, 1995). Additionally, Ghana accepted the call for 30 percent representation of women in all decision-making positions at all levels.

Unfortunately, the country was far from accomplishing these goals. It was therefore against this background that women's rights activists supported by NETRIGHT and ABANTU for Development 
(a non-governmental organisation) recognised the need to "rethink the concept of women's political empowerment and refashion the tools for lobbying and advocacy and the need to hold government accountable for the commitments made to women" (Mensah-Kutin, 2005, p. 7). The idea for a Women's Manifesto for Ghana was born.

The Women's Manifesto for Ghana was based on the experiences of other African women in Botswana, Namibia, South Africa, Tanzania and Uganda that had embarked on similar processes to mobilise women for consensus-building on critical issues of concern to women. Moreover, the development of a Women's Manifesto for Ghana was vital, as there was no consensus on how women's issues should be voiced and translated into state policy.

The Women's Manifesto Coalition (WMC) was made up of individual women, women's organisations and extended to include other political and socially conscious organisations such as civil society groups, non-governmental organisations, organised labour, the media, representatives from the state and political parties. The collective public action of the WMC enabled conscious Ghanaian women to break the shackles of quiet activism characterized by their existence as isolated individual entities in favour of a broadbased movement at the national level that advocated for women's rights.

In this regard, a series of national discussions were held to ensure that the broad Ghanaian citizenry participated in the development of The Women's Manifesto for Ghana. On 23 June 2003, the first deliberation was held with sixty-five gender activists, policymakers and civil society stakeholders (Mama, 2005; Kutin, 2005). They discussed the major issues of concern to women and explored the opportunities for increasing women's participation in the public sphere. This initial discussion was a success as women's rights activists and participants discovered that their inability to connect their problems with those of their peers kept them powerless and vulnerable. In addition, despite the heterogeneity of women in Ghana, they realised they all shared the experience 
of gender inequality, marginalisation and limited representation on the political scene. Participants were vocal about the social order that perpetuated injustice, deprivation and limited resources and opportunities to women (Mama, 2005; Tsikata, 2009).

The next step was to sell the idea of a Women's Manifesto for Ghana to women at the grassroots and to local decision makers. In this regard, the Manifesto Coalition organized a three-day meeting with female representatives from all the 110 district assemblies in the capital Accra, in 2003. This was a historic meeting as district assembly women from across the country met for the very first time. They discussed strategies through which they could achieve unanimity on broad gender questions, strengthen coalition-building efforts and increase women's effective participation in the political process, especially the upcoming 2004 elections. Dialoguing with women policy makers enabled women at the grassroots level to shift their consciousness and embrace a sense of ownership in The Women's Manifesto for Ghana (Mama, 2005).

A third consultative meeting was organized with executives of the seven registered political parties and their women's wings. It was imperative for women's right activists to acquaint themselves with how political parties work, how gender issues were incorporated into the framework of political parties and how women could be facilitated in playing an active role in these associations. This is because women's rights activists are concerned about the underrepresentation of women in politics, policy and decision-making levels as well as in public life in general (Tsikata, 2009; Manuh \& Anyidoho, 2008).

After these consultations, Drafting and Steering Committees were formed that made decisions on the process of developing and promoting the Manifesto. Key individuals involved in this process include: Rose Mensah-Kutin, Joseph Bogrebon Allan, Roselyn Baateokuo, Hillary Gbedemah, Adwoa Bame, Grace Afrifa, Sarah Quarcoo, and Dzodzi Tsikata. In April 2004, a draft was produced and used to organise broader regional consultations which included the media and parliamentarians. On 2 September 2004, The Women's 
Manifesto for Ghana was launched (Mama, 2005).

This document was made up of a preamble and ten thematic sections which explicitly outlined the common demands of Ghanaian women in order to truncate gender bias and power disequilibrium in the nation. These demands cover the themes of women's economic development; women and land; women, social policy and social development; women in politics, decision-making and public life; women, human rights and the law; discriminatory cultural practices; women and the media; women, conflict and peace, and women with special needs. In addition, there is an eleventh section which is a call to action for advocacy work.

The thematic areas can be divided into two broad categories. Namely, issues that can be ameliorated through legislation and governmental policies and issues embedded in Ghanaian cultural norms. However, women's rights activists believe that irrespective of these categories, the issues that underlie women's empowerment discourse are political in nature, thus, The Women's Manifesto for Ghana advocates political solutions. Three main issues at the heart of the Manifesto centre on women's economic self-reliance, women and decision-making, and greater representation in government.

Economic self-reliance as a form of empowerment is vital to Ghanaian women because the prevalence of poverty among women is attributed to poor social and economic policies that have been perpetuated over time. This situation coupled with overdependence on donor aid with its attendant conditionalities has affected women negatively. In order to enable women attain economic self-sufficiency, the Manifesto calls for a change in the structure of domestic roles performed by both sexes such that men and women equally discharge responsibilities at home. This would enable women engage in economic activities outside the home. For women who still perform majority of the household tasks, the Manifesto calls for an economic policy that incorporates domestic labour into the state's definition of economic activities, even though the practicality of this and how it is to be achieved was not selfevident. 
The quest for empowerment of women in Ghana is also linked with greater representation in governance and autonomy in making decisions concerning self-determination. Women's under-representation in governance is symptomatic of women's marginalisation in decision-making at the domestic level and in the public sphere. Beyond the barriers of an inadequate financial base to fund political campaigns and high levels of illiteracy among women, the Manifesto points to the gap between men and women in terms of education as a key bottleneck. The idea of increasing women's participation in governance is not merely a matter of motivating women to enter politics, rather it involves a change in socio-cultural policies that discriminate against female education and hinder women from gaining access to higher education. When this is done, the Manifesto asserts that women will have the opportunity to increase their participation in decision-making processes at the local and national level.

Historically, culture has been used as a tool to justify discriminatory practices against women in Ghana. Women are expected to submit to their husbands irrespective of the issues at stake and their submission is reinforced by religious doctrines. This cultural practice takes autonomy and self-determination away from women and invests it in the patriarchal society. Indeed, the application of this cultural dictum is inimical to women's reproductive health, especially with respect to the use of contraception. The Manifesto notes, "while awareness of contraception is over $90 \%$ in Ghana, only $22 \%$ of married women use contraception as compared to $32 \%$ of men. The figure is even lower among the poor" (The Women's Manifesto for Ghana, 2004, p. 43). The result is that some men refuse to allow their partners to use contraception for fear that it would encourage them to be promiscuous, thus leaving women without protection from unplanned pregnancies and sexually transmitted infections. This inability of women to actively and effectively participate in decision-making processes about their bodies in the family constitutes a form of powerlessness that the implementation of the Women's Manifesto seeks to end. 
More than a decade after the creation of The Women's Manifesto for Ghana, some of the demands in the document have been addressed. There was the passage of the Domestic Violence Bill (Act 732) in 2007, and the establishment of a Domestic Violence and Victims Support Unit(DOVVSU) in all ten regional capitals; the Enactment of the Human and Children Trafficking Act (Act 694) in 2005; the prohibition of Female Genital Mutilation (FGM) in 2006 and the Persons with Disability Law (Act 715) in 2006. The Regional Houses of Chiefs was expanded to include paramount queen mothers as well as the establishment of customary land secretariats throughout the country and a draft Land Bill which focuses on land tenure, administration and women's rights. Equally important are the introduction of a National Health Insurance Scheme in 2006 to enhance access to basic health care; implementation of the Free Compulsory Universal Basic Education (FCUBE); a school feeding programme that helps with the retention rate of female students; a Livelihood Empowerment Against Poverty Programme (LEAP) in 2008; a Social Protection Policy in 2016 and a free Senior High School education policy in 2017. The Government of Ghana ratified the Economic Community of West African States (ECOWAS) convention on Small Arms and Light Weapons in 2010 and set up the Ghana National Commission on Small Arms, in a bid to resolve latent and active communal conflicts in the country that lead to abject poverty, hardship and deprivation for women. Finally, in May 2015 the Ministry of Gender, Children and Social Protection adopted a National Gender Policy under the theme, Mainstreaming Gender Equality and Women's Empowerment into Ghana's Development Efforts.

On the whole, the formation of the WMC and its public education and mobilisation efforts led to some structural transformation of unjust power relations in the political arena. Ghanaian women who internalised their subordinate status began to develop critical consciousness about the unjust social structures and envisaged alternative political arrangements in which women's rights issues mattered. One of the practical manifestations of the 
effectiveness of The Women's Manifesto for Ghana has been the appointment of women into high profile public leadership positions. These include positions such a Chief Justice, Speaker of Parliament; Attorney General and Minister of Justice, Director of Immigration, Director of Prison Service; Electoral Commissioner, Commissioner of Insurance; Director of Ghana Education Service, and Minister of Education, among others. This is a victory for Ghanaian women who pushed for reforms and for their voices to be transformative because they need to be heard where decisions are made.

Despite these successes, progress in women's empowerment and collective action is never free from challenges. According Tsikata (2009) women have limited influence in political decision making and social norms and beliefs regarding women's abilities and gender roles limit women's voice in formal politics. In the case of the WMC, the expansion of its membership base and how to sustain collective action around the execution of the demands in the Women's Manifesto for Ghana has been a challenge (Tsikata, 2009, p.190). On the national level, Ghanaian women remained significantly under-represented at the highest level of political participation, as well as across public and private sectors. Jennifer Asuako, UNDR Gender Analyst notes that as at December 2016, Ghana had only 31 of its 275 parliamentarians as women with less than 30\% being Ministers of State and District Chief Executives (Asuako, 2016). This can be attributed to the unequal playing field created by political parties, the persistence of discrimination, gender bias, and the threat of violence, harassment and intimidation in political institutions. Clearly, there is the need for the state to meet more of the demands stated in The Women's Manifesto for Ghana in order for Ghanaian women to live dignified, healthy and empowered lives.

\section{Conclusion}

The journey to conscientise, empower and create an enabling environment for Ghanaian women to engage, negotiate and contest the paternalistic post-colonial state has been arduous but successful. There were ebbs and flows from the era of quiet activism and state 
co-optation in the 1980s, to the rebirth of women's activism in the early 1990s, courtesy of Ghana's Fourth Republic. By 2004, the desire of Ghanaian women's right activists to engage, challenge and negotiate with the state on women's right issues culminated in the creation of a living document, The Women's Manifesto for Ghana. This document marked a watershed moment in the contestation for gender equality and equity in post-independent Ghana.

Drawing its power from collective action in the serial murder cases, the passage of the Domestic Violence Bill and the establishment of The Women's Manifesto for Ghana document, Ghanaian women's mobilisation has come of age. It demonstrates that the agenda of the women's movement is concerned with activities that address women's rights issues at the policy level. The success of The Women's Manifesto for Ghana stems from the process of dialogue by the Women's Manifesto Coalition as a vital method in bringing about societal transformation characterized by increasing associational autonomy. During these consultations trust and mutuality was evident amongst the groups. Thus, The Women's Manifesto for Ghana became a collectively owned document that set out critical issues of concern to women in Ghana and makes demands for addressing them.

The Ghanaian state's casual approach to women's rights issues notwithstanding, fulfilled some of the Manifesto's demands. However, a comprehensive approach is needed to increase women's participation in power and decision-making and The Women's Manifesto for Ghana can serve as a gender check list and benchmark for measuring results of the advancement of women's political voice and leadership for years to come. All that is needed is for women's rights advocates in Ghana to remain as a collective and keep the momentum of their activism alive. 


\section{References}

Adjei, M. (1994). Death and pain, Rawlings' Ghana: The inside story. London: Blackline Publishing.

Adomako, A., \& Asiedu, A. (2012). Changing representations of women in Ghanaian popular music: marrying research and advocacy. Current Sociology, 60(2), 258-79.

Aidoo, A. (1985). Asante queen mothers in government and politics in the nineteenth century. In F. Steady (Ed.), The Black woman crossculturally (pp. 65-77). Cambridge, MA: Schenkman.

Akurang-Parry, K. (2004). Aspects of elite women's activism in the Gold Coast, 1871-1890. International Journal of African Historical Studies, 37(3), 463-482.

Akyeampong, E., \& Obeng, P. (1995). Spirituality, gender, and power in Asante history. International Journal of African Historical Studies, 28(3), 481-508.

Allah-Mensah, B. (2005). Women in politics and public life in Ghana. Accra: Friedrich Ebert Stiftung.

Allman, J., \& Tashjian, V. (2000). I will not eat stone: A woman's history of colonial Asante. Portsmouth, NH: Heinemann Press.

Allman, J., Geiger, S., \& Nakanyike, M. (2002). Women in colonial histories. Bloomington, IN: Indiana University Press.

Alsop, R., Heinsohn, N., \& Somma, A. (2005). Measuring empowerment; An analytic framework. In R. Alsop (Ed.), Power, rights and property: concepts and connections (pp. 120-125). Washington, DC: World Bank.

Amadiume, I. (1987). Male daughters and female husbands: Gender and sex in an African society. London: Zed Books.

Anunobi, F. (2002). Women and development in Africa: From marginalization to gender inequality. African Social Science Review, 2, 41-63.

Arhin, K. (1983). The political and military roles of Akan women. In C. Oppong (Ed.), Female and male in West Africa (pp.91-98). London: George Unwin and Allen.

Armah, G. (2000, July 3). Another mystery murder rocks Accra: Victim no. 25 and still no clues. Daily Graphic, p. 1.

Asuako, J. (2017). Women's political participation: A catalyst for gender equality and women's empowerment in Ghana. Retrieved from www.gh.undp.org/content/ghana/en/home/ourperspectivearticles /2017/.html.

Batliwala, S. (1993). Empowerment of women in south Asia: Concepts and practices. New Delhi: FAO and Asian-South Pacific Bureau of Adult Education.

Berger, I. (2003). African women's history: Themes and perspectives. Journal of Colonialism and Colonial History, 4(1),1-11.

Bradshaw, S. (2013). Women's decision-making in rural and urban households in Nicaragua: The influence of income and ideology. Environment \& Urbanization, 25(1), 81-94. 
Brydon, L. (1996). Women chiefs and power in the Volta region of Ghana. Journal of Legal Pluralism and Unofficial Law, 37-38, 227-247.

Coffe, H., \& Bolzendahl, C. (2011). Gender gaps in political participation across sub-saharan African nations. Social Indicators Research, 102(2), 245-264.

Cornwall, A., \& Anyidoho, N.A. (2010). Women's empowerment: Contentions and contestations. Development, 53(2), 144-149.

Cornwall, A. (2016). Women's empowerment: what works? Journal of International Development, 28, 342-359.

Darkwah, A. (2016). Globalisation, development and the empowerment of women. In J.

Steans \& D. Tepe (Eds.), Handbook of gender in international relations (pp.386393). London: Edward Elgar.

Eyben, R., \& Napier-Moore, R. (2009). Choosing words with care? Shifting meanings of women's empowerment in international development. Third World Quarterly, 30 (2), 285-300.

Fallon, K. (2008). Democracy and the rise of women's movement in subSaharan Africa. Baltimore, MD: Johns Hopkins University Press.

Ghana News Agency. (1982, March 1). Control prices out. Daily Graphic, p. 2.

Gocking, R. (2005). The history of Ghana. Westport, CO: Greenwood Publishing.

Government of Ghana. (1960). Parliamentary debates: Official report. Accra: Government of Ghana.

Graphic Reporter. (2001, May 16). I killed 8 women: Serial killer confesses. Daily Graphic, p. 1.

Hamah, V. (2015). Women's participation in Ghanaian politics: An assessment of the opportunities and limitations (MPhil thesis). University of Ghana, Accra, Ghana. Retrieved from http://ugspace.ug.edu.gh.

Kabeer, N. (1994). Reversed realities: Gender hierarchies in development thought. London: Verso.

Kufour, J. A. (2001). The inaugural address of president John Agyekum Kufour. Retrieved from http//www.Ghanaweb.com/GhanaHomePage/republic/ prez-inug-adr.php.

Kufour, J. A. (2005). The Inaugural Address of president John Agyekum Kufour. Retrieved from http//www.Ghanaweb.com/GhanaHomePage/ republic/prez-inug-adr.php.

Malhotra A., Schuler, S.R., \& Boender, C. (2002). Measuring women's empowerment as a variable in international development. Washington, DC :World Bank:

Mama, A. (2000). Feminism and the state in Africa: Towards an analysis of the national machinery for women in Africa. Accra: Third World Network.

Mama, A. (2005). The Ghanaian women's manifesto movement: In conversation with Dzodzi Tsikata, Rose Mensah-Kutin and Hamida Harrison. Feminist Africa, 4, 124-138. 
Manuh, T. (1991). Women and their organisation during the Convention People's Party period. In K. Arhin (Ed.), The life and work of Kwame Nkrumah (pp. 108-134). Accra: Sedco Publishing.

Manuh, T. (1993). Women, the state and society under the PNDC. In E. Gyimah-Boadi (Ed.), Ghana under PNDC rule (pp. 176-195). Dakar: CODESRIA.

Manuh,T., \& Anyidoho, N.A. (2008). Taking the level? A study of discourses and practices on women's empowerment by Ghana's Ministry of Women and Children's Affairs (MOWAC). Conference presentation Pathways of Women's Empowerment: What are we learning? 20-24 January 2008.

Mensah-Kutin, R. (2005). The coalition on the women's manifesto for Ghana: Lesson from an alliance-building initiative. A paper presented at AWID forum in Bangkok, Thailand, Unpublished.

Narayan, D. (2002). Empowerment and poverty reduction: A sourcebook. Washington, DC: World Bank.

Nugent, P. (1996). Big men, small boys and politics in Ghana: Power, ideology and the burden of history, 1982-1994. London: Frances Pinter.

Nugent, P. (2015). A decade of Ghana: Politics, economy and society, 20042013. Leiden: Brill.

Nzomo, M. (1994). The status of women's human rights in Kenya and strategies to overcome inequalities. Journal of Opinion, 22, 17-20.

Odotei, I. (2006). Women in male corridors of power. In I. Odotei \& A. Awedoba, (Eds.), Chieftaincy in Ghana: Culture, governance and development (pp.81-100). Accra: Sub-Saharan Publishers.

Okrah, K. (2018). The dynamics of gender roles and cultural determinants of African women's desire to participate in modern politics. Journal of Global Engagement and Transformation, 1(2), 1-15.

Oquaye, M. (2004). Politics in Ghana, 1982-1992: Rawlings, revolution and populist democracy. Accra: Tornado Publications.

Prah, M. (2003). Chasing illusions and realising visions: Reflections on Ghana's feminist experience. Dakar: Codesria.

Prah, M. (2007). Ghana's feminist movement: Aspirations, challenges, achievements. Accra: Woeli Press.

Rowlands, J. (1997). Questioning empowerment: Working with women in Honduras. Oxford: Oxfam Publishing.

Sen, G. (1997). Empowerment as an approach to poverty. Working paper series 97.07. UNDP Human Development Report. New York: UNDP.

Sheldon, K. (2017). African women: Early history to the 21st century. Bloomington, IN:Indiana University Press.

The Coalition on the Women's Manifesto for Ghana. (2004). The women's manifesto for Ghana. Accra: The Coalition on the Women's Manifesto for Ghana. 
Tripp, A., \& Casimiro, I. (Eds.). (2009). African women's movements: Transforming political landscapes. Cambridge, UK: Cambridge University Press.

Tsikata, D. (1989). Women's political organisations, 1951-1987. In E. Hansen \& K. A. Ninsin (Eds.), The state, development and politics in Ghana (pp. 73-93). London CODESRIA.

Tsikata, D. (2009). Women's organizing in Ghana since the 1990s: From individual organizations to three coalitions. Development, 52, 185-192.

United Nations Development Programme. (2016). Sustainable Development Goals. Retrieved from www.undp.org/content/undp/en/home/ sustainable-development-goals.html.

United Nations Development Programme. (2018). Human development reports: 2018 statistical update. Retrieved from www.hdr.undp.org/ en/countries/profiles/GHA.United States Bureau of Fiscal Services. (1982). Treasury reporting rates of exchange as of March 31, 1982. Washington, DC: United States Department of Treasury.

World Bank. (2011). World Development Report 2012: Gender equality and development. Washington, DC: World Bank. 